\title{
Induction of epstein-barr virus (EBV) lytic cycle in vitro causes lipid peroxidation, protein oxidation and DNA damage in lymphoblastoid B cell lines
}

\author{
Bochra Gargouri ${ }^{*}$, Rihab Nasr ${ }^{\dagger}$, Malek Mseddi, Riadh benmansour and saloua Lassoued
}

\begin{abstract}
Background: We investigated the oxidative modifications of lipids, proteins and DNA, potential molecular targets of oxidative stress, in two lymphoblastoid cell lines: B95-8 and Raji, after EBV lytic cycle induction. Conjugated dienes level was measured as biomarker of lipid peroxidation. Malondialdehyde adduct and protein carbonyl levels, as well as protein thiol levels were measured as biomarkers of protein oxidation. DNA fragmentation was evaluated as biomarker of DNA oxidation.

Results: After $48 \mathrm{~h}$ (peak of lytic cycle), a significant increase in conjugated dienes level was observed in B95-8 and Raji cell lines ( $p=0.0001$ and $p=0.019$ respectively). Malondialdehyde adduct, protein carbonyl levels were increased in B95-8 and Raji cell lines after EBV lytic cycle induction as compared to controls (MDA-adduct: $p=$ 0.008 and $p=0.006$ respectively; Carbonyl: $p=0.003$ and $p=0.0039$ respectively). Proteins thiol levels were decreased by induction in B95-8 and Raji cell lines $(p=0.046 ; p=0.002$ respectively). DNA fragmentation was also detected in B95-8 and Raji cell lines after EBV lytic cycle induction as compared to controls.

Conclusion: The results of this study demonstrate the presence of increased combined oxidative modifications in lipids, proteins in B95-8 and Raji cells lines after EBV Iytic cycle induction. These results suggest that lipid peroxidation, protein oxidation and DNA fragmentation are generally induced during EBV lytic cycle induction and probably contribute to the cytopathic effect of EBV.
\end{abstract}

Keywords: B95-8 cell line, Raji cell line, oxidative stress, Epstein Barr Virus, lymphoblastoid cell line

\section{Background}

Epstein Barr virus (EBV) is a ubiquitous gammaherpesvirus that infects more than $90 \%$ of the human population. The EBV can infect its target cells in both a latent and a lytic mode. The latent cycle is characterized by the expression of six Epstein-Barr nuclear antigens (EBNAs), three latent membrane proteins LMP1, LMP2A, and LMP2B, two untranslated RNAs (EBER), and a family of transcripts from the BMH1A region of the genome [1,2]. Upon EBV reactivation, two key immediate early (IE) lytic genes, BZLF1 and BRLF1, encoding Zta (BZLF1 transcription activator) and Rta (BRLF1 transcription activator) respectively, are

\footnotetext{
*Correspondence: bochra.gargouri@yahoo.fr

† Contributed equally

Unité de Biotechnologie et Pathologies, Institut Supérieur de Biotechnologie de Sfax, Tunisia
}

(c) 2011 Gargouri et al; licensee BioMed Central Ltd. This is an Open Access article distributed under the terms of the Creative Commons Attribution License (http://creativecommons.org/licenses/by/2.0), which permits unrestricted use, distribution, and reproduction in any medium, provided the original work is properly cited. transcribed, and consequently activate several downof viral gene expression [3]. The latent form of EBV can be induced to enter the lytic form in vitro by treatment with various chemicals, including 12- 0-tetradecanoylphorbol-13-acetate (TPA) [4], halogenated pyrimidine [5], n-butyrate [6], calcium ionophores [7]. These inducers act through different signalling pathways to transactivate gene of EBV, which encodes the ZEBRA protein. The expression of ZEBRA protein then transactivates immediate early and early genes of EBV, and thereby induces the lytic cycle $[8,9]$.

EBV is associated with a spectrum of malignancies of lymphoid and epithelial cell origin, such as Burkitt's lymphoma [10], nasopharyngeal carcinoma (NPC) [11], and gastric carcinoma [12]. The role of EBV in malignancy was largely studied and latent EBV antigens such 
as LMP or EBNA were generally incriminated [13-15]. The fact that all EBV-associated malignancies have a predominantly latent pattern of viral gene expression led to the assumption that only the latent phase of viral gene expression is important during the development of EBV associated malignancies. Nevertheless, a small number of lytically infected cells are frequently detected in biopsies of EBV-associated lymphoproliferative diseases (LPDs) in immunosuppressed individuals. Lytic replication has been observed at the site of tumor development in posttransplant lymphoproliferative disorder (PTLD) [16] as well as in Burkitt's lymphoma [17]. In addition, Hong et al. have shown that EBV mutants that cannot undergo lytic viral replication are defective in promoting EBV-mediated LPD [18]. Moreover, an increasing number of diseases were found to be associated with EBV lytic cycle and exhibit an oxidative stress state at the same time, such as rheumatoid arthritis $[19,20]$, and infectious mononucleosis [21].

A lot of evidences demonstrated that EBV is implicated in the genesis of oxidative damages in vitro or in vivo and that could participate in the pathogenicity of the EBV. An excessive production of reactive oxygen specie (ROS) was highlighted in EBV positive lymphoblastoid cell lines transformed in vitro [22] or derived from Burkitt's lymphoma [23]. In addition, oxidative damage was determined during the course of acute EBV infection [24] and replication [25] in lymphoblastoid cell lines.

Oxygen free radicals or, more generally, ROS, are products of normal cellular metabolism. ROS are well recognised for playing a dual role as both deleterious and beneficial species, since they can be either harmful or beneficial to living systems [26]. Damage has been reported to occur on all components of biological systems (DNA, RNA, lipids, proteins, carbohydrates, lowmolecular-mass species, antioxidants) due to the high reactivity of many oxidants [27]. Proteins are likely to be major targets, as a result of their abundance in cells (proteins compose $70 \%$ of the drymass of most cells), and their rapid rates of reaction both with many radicals and with other oxidants (peroxides, excited states, peroxynitrite, chloramines, ozone) [27]. Otherwise, DNA damage is one of the more reliable markers to detect oxidative stress $[28,29]$.

However, there is no adequate knowledge in the literature about protein and DNA modifications in cells after EBV lytic cycle induction. Many different types of protein oxidative modifications can be induced by free radicals [30,31]. Protein carbonyl, protein thiol formation had been accepted as a phenomenon of protein oxidation [32].

This study sought the effect of virus replication on lipids, proteins and DNA oxidation of two lymphoblastoid cells lines B95-8 and Raji. The induction of the lytic cycle was done by TPA. The lipids, proteins and DNA damages were then determined after $48 \mathrm{~h}$, the peak of lytic cycle [33], by measuring the level of conjugated dienes as parameters of lipids peroxidation, malondialdehyde adduct, protein carbonyl and protein thiol as parameters of proteins oxidation, and the DNA fragmentation assays as marker of DNA damage.

\section{Results}

\section{Evaluation of lipid peroxidation (LPO)}

CD level was measured $48 \mathrm{~h}$ after induction of the lytic cycle to evaluate lipid peroxidation. The study was performed in parallel cultures with or without TPA treatment. Our data show a significant rise in CD level in B958 and Raji cell lines after EBV lytic cycle induction ( $\mathrm{p}=0.0001$ and $\mathrm{p}=0.019$ respectively) (Figure 1 ).

A comparison of differences between basal and post induction $\mathrm{CD}$ level was monitored. A significant rise in CD level was observed in B958 cell line as compared to CD level in Raji cell line ( $\mathrm{p}=0.01)$.

\section{Evaluation of MDA adduct}

MDA adduct level was monitored in B958 and Raji cell lines after $48 \mathrm{~h}$ of lytic cycle induction. MDA adduct level was low in B958 and Raji cell line without TPA treatment. Our data show a significant rise in MDA adduct level in B958 and Raji cell lines after EBV lytic cycle induction $(\mathrm{p}=0.008$ and $\mathrm{p}=0.006)$ (Figure 2).

The deviation between basal level and post induction level of MDA adduct was higher in B958 than in Raji cell line. $(\mathrm{p}=0.08)$.

\section{Evaluation of protein carbonyl and SH level}

PC and SH levels were assessed in B958 and Raji cells after $48 \mathrm{~h}$ of lytic cycle induction to determine proteins oxidation. A significant rise in PC level was observed in B958 and Raji cell lines, $48 \mathrm{~h}$ after EBV lytic cycle induction as compared to controls $(\mathrm{p}=0.0030$ and $\mathrm{p}=$ 0.0039 respectively). Protein thiol level was decreased by induction in B95-8 and Raji cell lines ( $\mathrm{p}=0.046$; $\mathrm{p}=$ 0.002 respectively) (Figure 3 and 4).

As evidenced with CD and MDA adduct, our result show a significant rise in carbonyl level as well as a significant decrease in SH level in B95-8 than in Raji cell line $(\mathrm{p}=0.01$ and $\mathrm{p}=0.01$ respectively).

\section{Evaluation of DNA fragmentation}

To investigate the DNA fragmentation, B95-8 and Raji cells were treated with $8 \mathrm{nM}$ TPA, and DNA was isolated and analyzed by agarose gel electrophoresis. These experiments demonstrated that DNA from B95-8 and Raji cells after EBV lytic cycle induction was fragmented (Figure 5). 


\section{Conjugated Diene}

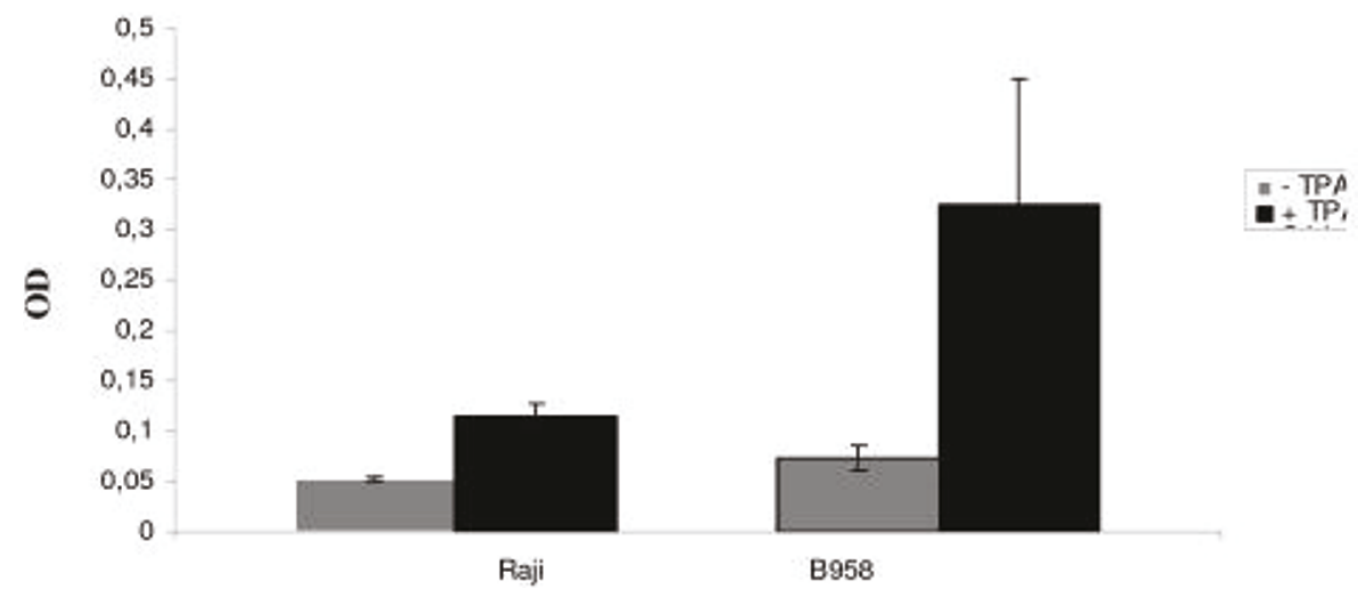

Figure 1 Illustrates conjugated diene level. To evaluate lipid peroxidation, CD level was measured $48 \mathrm{~h}$ after induction of the lytic cycle. The study was performed in parallel cultures with or without TPA treatment. After $48 \mathrm{~h}$, a significant increase in CD level was observed in B95-8 and Raji cell lines ( $p=0.019$ and $p=0.0001$ respectively).

\section{Discussion}

EBV is implicated in the generation of oxidative stress both in vivo, in some EBV associated malignancies and diseases such as NPC [34] and in vitro, in EBV-infected cell lines [23].

In a previous report, we demonstrated that EBV lytic cycle induction in lymphoblastoid cell line is responsible for the occurrence of oxidative stress by an increase in MDA level and a disturbance of SOD and CAT activities [25]. However, the direct role of EBV replication or the expression of lytic viral antigens in the genesis of proteins and DNA oxidation has not been investigated.

For these reasons, we investigated the effect of lytic cycle induction on the proteins oxidation, lipids peroxidation and DNA fragmentation of two lymphoblastoid cells lines: B958 and Raji. We chose to work with the minimal and sufficient concentration of TPA inducing EBV lytic cycle which is $8 \mathrm{nM}$. This concentration is very low, compared to the concentrations that will induce oxidative stress $(1.5-15 \mu \mathrm{M})$ [22], and this dose did not trigger stress in the EBV negative cell line (DG75) treated in the same conditions [35].

A significant rise in CD levels was observed in Raji and B958 cell lines $48 \mathrm{~h}$ after EBV lytic cycle induction. We observed an increase in CD level in the two cell lines, indicating the presence of oxidative stress as a consequence of induction of the lytic cycle.

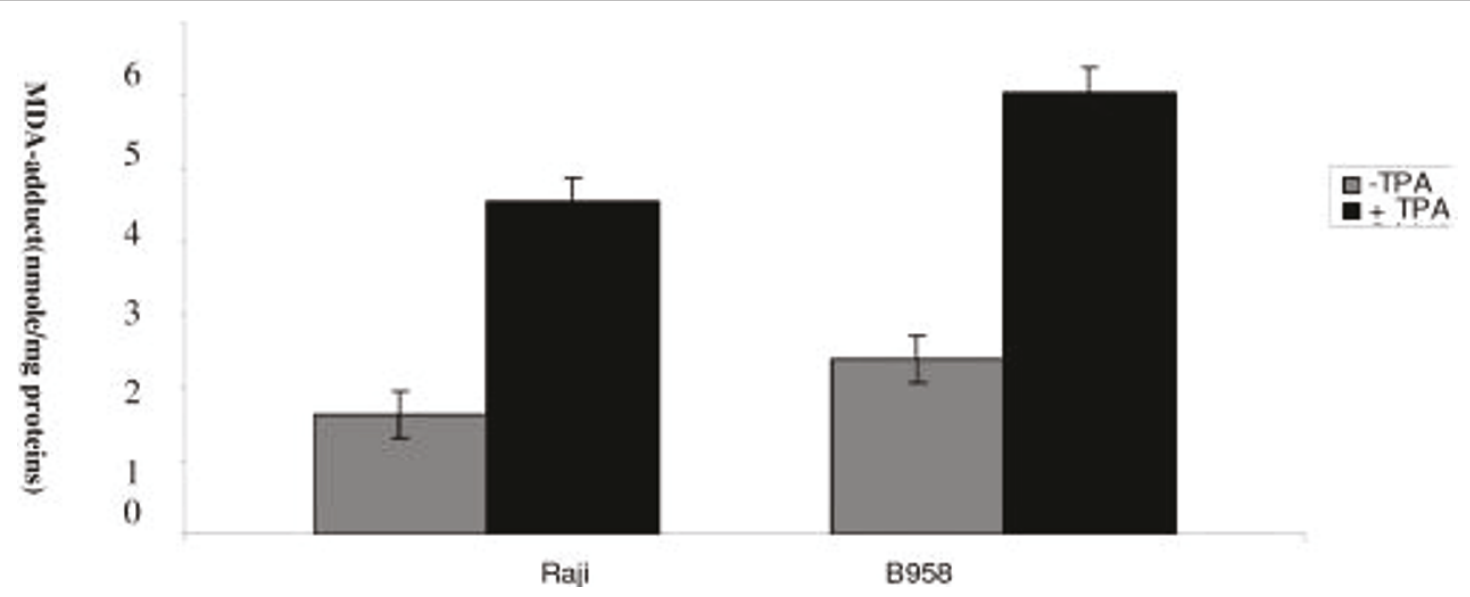

Figure 2 Illustrates MDA adduct level. MDA adduct level was measured in B958 and Raji cell line after $48 \mathrm{~h}$ of lytic cycle induction. Malondialdehyde adduct level was increased in B95-8 and Raji cell lines after EBV lytic cycle induction as compared to controls ( $p=0.008$ and $p$ $=0.006$ respectively). 


\section{Carbonyl level}

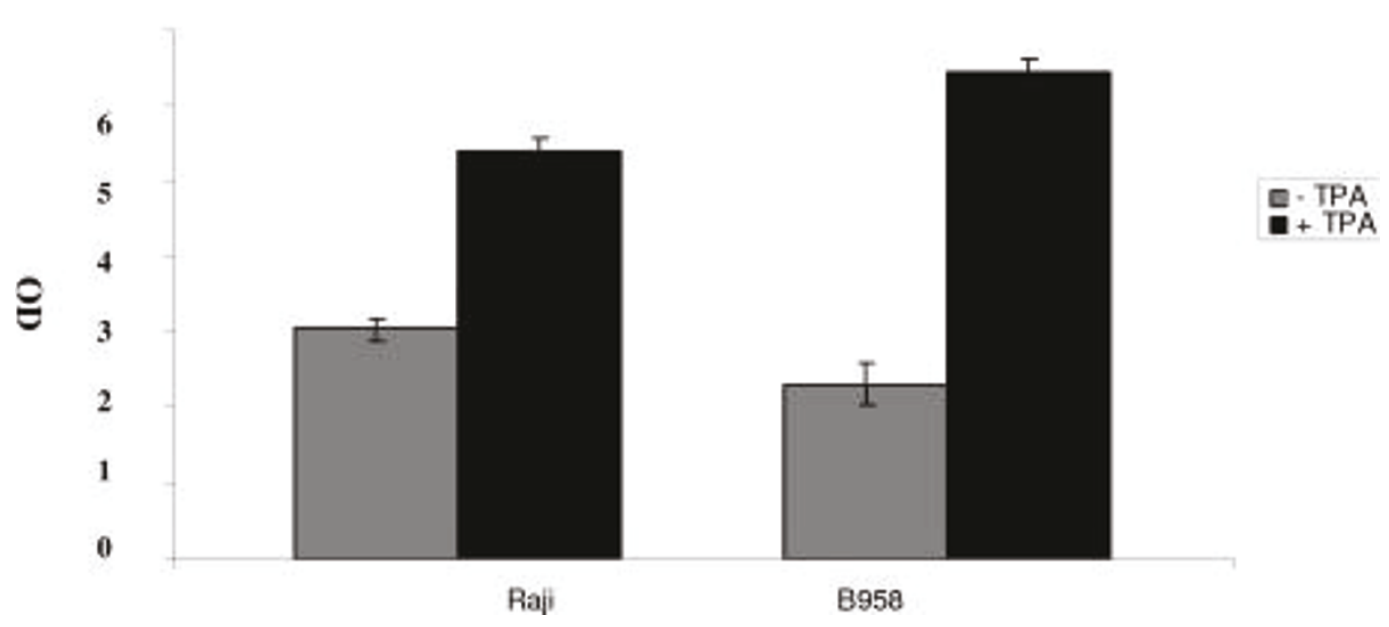

Figure 3 Illustrates protein carbonyl level. PC level was assessed in B958 and Raji cell line after 48 h of lytic cycle induction to determine protein oxidation. A significant rise in PC level was observed in B958 and Raji cell line $48 \mathrm{~h}$ after EBV lytic cycle induction as compared to controls ( $p=0.0030$ and $p=0.0039$ respectively).

Many different types of protein oxidative modifications can be induced by free radicals. Their oxidative damage can be evaluated by different ways, such as protein carbonyls, MDA adduct as well as SH level.

Protein carbonyls determination has been particularly proposed as a marker of oxidative stress, since they form early and they are generally stable [32].

Our data have show a significant rise in PC and MDA adduct levels as well as a decrease in SH level in Raji and B958 cells line, $48 \mathrm{~h}$ after EBV lytic cycle induction. Taken together, these results demonstrate protein oxidation during lytic cycle induction. Oxidized proteins cause major physiological perturbations including loss of structure and function [36]. Besides, previous studies have show that oxidatively modified proteins lead to the genesis of new epitopes that incite autoantibody production. Protein oxidation causes conformational changes, which include the exposure of the hydrophobic regions of the proteins, explaining the increased interaction between antibodies and antigens after oxidation [36]. In fact, an increasing

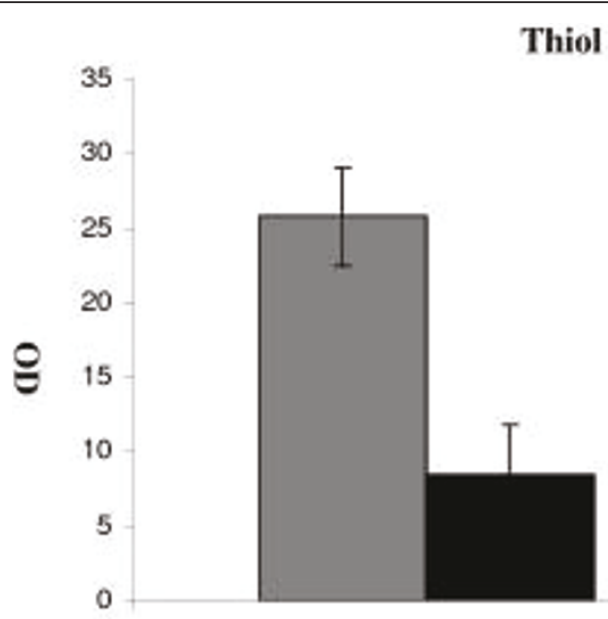

Paji

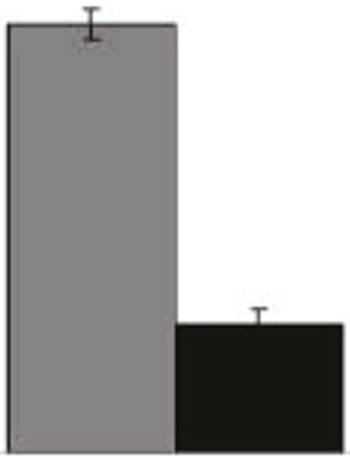

B958

Figure 4 Illustrates protein thiol level. Proteins thiol was monitored in B958 and Raji cell lines after 48 h of lytic cycle induction. Proteins thiol level was decreased by induction in B95-8 and Raji cell lines ( $p=0.046 ; p=0.002$ respectively). 


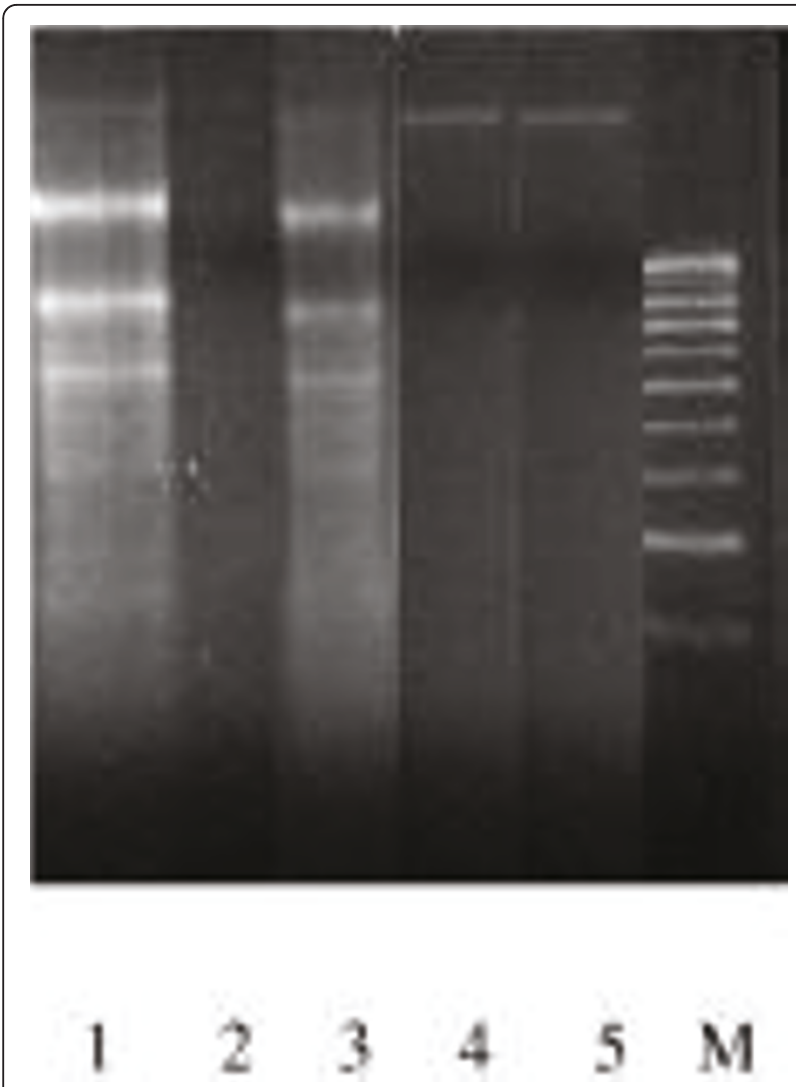

Figure 5 Agarose gel analysis of DNA from B958 and Raji cells. The study was performed in parallel cultures with or without TPA treatment. TPA treatment (lanes 1 (B958) and 3 (Raji)), untreated cells (lanes 2 (B958) and 4 (Raji)) and untreated lymphocytes used as control (lane 5). B95-8 and Raji cells were harvested at $48 \mathrm{~h}$ after EBV lytic cycle induction, and analyzed by $2 \%$ agarose gel. EBV lytic cycle induction causes DNA fragmentation in B95-8 as well as Raji cells.

number of autoimmune diseases were found to be associated with EBV lytic cycle and exhibit an oxidative stress state at the same time, such as rheumatoid arthritis [36].

Our data demonstrated that oxidative damage was higher in $\mathrm{B} 958$ as compared to Raji cell line. Interesting, B958 cell line can produce active EBV viral particles [37], contrarily to Raji cell line. So, our results reinforce our suggestion in our previous study, in which we suggested that an EBV viral program further down the lytic pathway may be responsible for observed oxidative stress. Raji is a Burkitt's lymphoma-derived cell line, which does not produce viral particles, because of the total inhibition of viral DNA synthesis $[4,38]$. However, lipid peroxidation and protein oxidation were observed after EBV lytic cycle induction, indicating that virus replication is not required for inducing oxidative stress. Other viral antigens, which continue to be expressed in Raji such as BZLF1, BRLF1, DNA polymerase, TK, and DNase, were probably responsible for the observed oxidative damage [39-41].
DNA fragmentation was detected in B95-8 and Raji cell lines after EBV lytic cycle induction as compared to controls. In fact, DNA damage is described in biopsies nasopharyngeal carcinoma patients [42], where EBV seems to play a crucial role [43]. Our results are in harmony with Michiko study, who reported a fragmentation of chromosomal DNA during EBV lytic cycle induction in Raji cell line [44]. Michiko suggested that EBV-specific early proteins participate in fragmentation of chromosomal DNA, since Phosphonoacetic acid, an inhibitor of EBV DNA polymerase, did not inhibit fragmentation of chromosomal DNA.

In our study, oxidative stress causes lipid peroxidation and protein oxidation. In addition, it is well known that ROS induce DNA strand breaks in human lymphocytes [45]. For these reasons, we suggest that ROS production causes DNA fragmentation. Our results is not in contradiction to thus presented by Michiko, since it has been shown that ROS regulate a spectrum of cellular responses, including $\mathrm{P} 53$, heat shock proteins, transcription factor NF- $\kappa \mathrm{B}$, and AP-1 [46-51]. Among them, P53, $\mathrm{NF}-\kappa \mathrm{B}$, and AP-1 have been reported to regulate Epstein-Barr virus immediate-early gene BZLF-1, the key molecule responsible for the reactivation of EBV [49-51]. Also, we have previously reported that $\mathrm{H}_{2} \mathrm{O}_{2}$ and $\mathrm{FeSO}_{4}$ induce BZLF-1 gene expression [24]. However, whether ROS productions, during lytic cycle induction induce DNA degradation directly or indirectly by other protein expression has to be defined.

It is well know that cytokines were among those first reported to generate ROS in nonphagocytic cells. It is generally accepted that ROS generated by these ligand/ receptor-initiated pathways can function as true second messengers and mediate important cellular functions such as proliferation and programmed cell death [52]. However, in lymphoblastoid cell lines, EBV lytic cycle induction downregulate cytokine genes expression such as (TNF)- $\alpha$ and interferon (INF) $-\gamma$ receptor $[53,54]$, and inhibits interferon regulatory factor (IRF)-7 mediated induction of IFN- $\alpha$ and $\beta$ genes expression [55].

In lymphoblastoid cell line, several pathways could be a source of ROS production such as mitochondria or NADPH oxydase. In fact, Lajeunesse et al reported that BZLF-1 gene expression in human cell lines results in a dramatic reorganization of mitochondria accompanied by a significant alteration of mitochondrial membrane potential, which can be a sign of an increase in ROS production caused by the damage of the mitochondrial electron transport system [56].

Martin et al. reported that infection of neutrophils by EBV in vitro, rapidly reduces their survival, as confirmed by DNA staining with propiduim iodide and Hoechst 33342 and by DNA analysis [57]. Larochelle et al. demonstrated that in vitro EBV infection drastically increases 
the rate of spontaneous neutrophils apoptosis [58]. Flow cytometry analyses have revealed that $77 \%$ of neutrophils were apoptotic after $20 \mathrm{~h}$ post-infection, as compared to $22 \%$ in uninfected cells. However, the mechanism initiating the apoptotic process in EBV infected neutrophils remains unknown. Valko et al. reported an inhibition of protein kinase $\mathrm{C}$ (PKC) translocation and activation during EBV lytic cycle. It is well know that PKC was described as a source of ROS production [26].

In lyphoblastoid cell line, we described an oxidative stress status, $48 \mathrm{~h}$ after EBV activation, which correspond of a peak of EBV lytic cycle induction and we don't observe death of cells.

Hitochi et al. reported that treatment of Raji cells with flavonoids, quercetin resulted in effective inhibition of EA induction by TPA. None of the other flavonoids such as rutin, catechin and fi-naphthoflavone affected the induction of EBV-EA by TPA [59].

We reported that EBV replication induced oxidative stress in lymphoblastoid cell lines. In a previous study we have demonstrated that oxidative stress caused EBV lytic cycle induction as demonstrated by BZLF-1 gene expression. Thus, a vicious cycle may be initiated, whereby replication of EBV and ROS production amplify one another. This may lead to an increase in the number of EBV-infected cells and thus favor the development of EBV associated diseases, especially in immunodeficient individuals. The use of therapeutic drugs such as chemotherapy or immunosuppressive drug, which are known to induct oxidative stress may up-regulate the expression of BZLF-1, and may be a risk factor for EBV reactivation [60,61]. Inhibition of ROS may be useful in prevention or in the treatment of EBVinduced diseases.

In summary, EBV lytic cycle induction was able to damage lipids, proteins and DNA, crucial biomolecules in living cells. Same damages were observed in EBV associated malignancies such as DNA damage in nasopharyngeal carcinoma biopsies patients, and proteins modification in autoimmunes diseases. This investigation may provide important clues to the mechanisms involved in the development of cancer and autoimmunes deseases.

\section{Materials and methods}

\section{Cell line and culture conditions}

Cell lines and culture conditions

- Raji is a human Burkitt's lymphoma-derived cell line, harboring the latent form of EBV cycle [62].

- B95-8 is a lymphoblastoid cell line established from peripheral blood lymphocytes of a cotton-top marmoset (Saguinus Oedipus) following in vitro infection with EBV [37]. A small fraction (1-3\%) of current batches of B95-8 cells spontaneously enter the viral lytic cycle.

All the cell lines were grown in RPMI 1640 medium (Gibco) supplemented with $10 \%$ fetal calf serum (FCS) and $2 \mathrm{mM} \mathrm{L-glutamine} \mathrm{in} \mathrm{tissue} \mathrm{culture} \mathrm{flasks}$ (Nunc). They were passaged twice a week and kept at $37^{\circ} \mathrm{C}$ in a humidified atmosphere of $95 \%$ air and $5 \%$ $\mathrm{CO} 2$.

\section{TPA treatment}

For the induction of the lytic cycle, $3 \times 10^{6}$ cells were stimulated with $8 \mathrm{nM}$ TPA for $2 \mathrm{~h}$, when the cells were in logarithmic phase growth, usually $48 \mathrm{~h}$ after placing them in culture. The cells were washed two times with Phosphate buffer saline (PBS) and further incubated for $48 \mathrm{~h}$ in fresh culture medium [62].

\section{Preparation of cell extracts}

Cells were centrifuged at 3,000 rpm for $10 \mathrm{~min}$. The pellet was resuspended in $500 \mu \mathrm{l}$ of deionized water and lysed by five cycles of sonication during $20 \mathrm{~s}$ at $37 \%$ (Sonisc, vibracell).

\section{Protein determination}

Proteins were determined using the Protein Assay Kit from Bio-Rad (France) and bovine serum albumin served as the standard.

\section{Conjugated Dienes}

Conjugated diene level was evaluated as described by Kurien and Scofield [63] with modification. $25 \mu \mathrm{l}$ of cells lysat were extracted with $3 \mathrm{ml}$ chloroform/methanol $(2: 1, \mathrm{v} / \mathrm{v})$. After centrifugation at 3,000 rpm for 15 min, $2 \mathrm{ml}$ of organic phase was transferred into another tube and dried at $45^{\circ} \mathrm{C}$. The dried lipids were dissolved in $2 \mathrm{ml}$ of methanol and absorbance at $233 \mathrm{~nm}$ was determined. It corresponds to the maximum absorbance of the extracted compounds.

\section{Determination of protein thiol levels}

Protein thiols were quantified spectrophotometrically using 5,5-dithionitrobenzoic acid (DTNB); $250 \mathrm{ml}$ of freshly prepared $10 \mathrm{mM}$ DTNB in $0.05 \mathrm{M}$ phosphate buffer $\mathrm{pH} \mathrm{8}$, were added to $50 \mathrm{ml}$ of cell lysat in 1200 $\mathrm{ml}$ of $0.05 \mathrm{M}$ phosphate buffer. After incubation in the dark for $15 \mathrm{~min}$ at room temperature, the release of 5thiobenzoic acid was quantified by measuring the absorbance at $412 \mathrm{~nm}$ and converted to absolute values using $\mathrm{N}$-acetyl cysteine as standard (0-0.1 mM). A correlation coefficient of $\mathrm{r} 2=0.999$ was obtained. The absorbance of samples lacking DTNB was subtracted to account for the background absorbance at $412 \mathrm{~nm}$. Samples were analysed in duplicate. 


\section{Detection of MDA-protein}

The MDA content was assessed by colorimetric assay, as described by Palacio et al [64]. This assay measures the MDA bound to proteins. In brief, cells lysats were precipitated twice with sulfuric acid and phosphotungstic acid. After centrifugation, the pellet was diluted with $800 \mathrm{ml}$ of distilled water. Then, $10 \mathrm{ml}$ of $0.14 \mathrm{mM}$ ethylenediaminetetraacetic acid (EDTA), $80 \mathrm{ml}$ of $0.2 \%$ butylated hydroxytoluene in ethanol (BHT) and $200 \mathrm{ml}$ of $1 \%$ thiobarbituric acid (TBA) were added and incubated at $100^{\circ} \mathrm{C}$ for $60 \mathrm{~min}$. An equal volume was extracted with butanol and centrifuged. Finally, $250 \mathrm{ml}$ were removed from the butanolic phase and absorbances at 540 and $620 \mathrm{~nm}$ were determined with a Biochrom Libra S32 spectrophotometer. 1,1,3,3-Tetraethoxypropane (Sigma) was used as standard. A standard curve $(0.05,0.1,0.25,0.5,1,2.5,5 \mathrm{nM})$ was included in every assay. A correlation coefficient of $\mathrm{r} 2=0.989$ was obtained. All the samples were treated in duplicate and the results are given as the mean values.

\section{Protein carbonyl (PC) levels}

PC levels were measured according to the method based on spectrophotometric detection of the reaction of 2,4dinitrophenylhydrazine (DNPH) with protein carbonyl to form protein hydrazones [30]. Briefly, after precipitation of protein with an equal volume of $1 \%$ trichloroacetic acid, the pellet was resuspended in $10 \mathrm{mM}$ DNPH in $2 \mathrm{~N} \mathrm{HCl}$ or with $2 \mathrm{~N} \mathrm{HCl}$ as control blank. Next, after the washing procedure with 1:1 ethanol/ethylacetate, the final pellet was dissolved in $6 \mathrm{M}$ guanidine. The carbonyl group was determined from the absorbance at 370 $\mathrm{nm}$. The results were expressed as nanomoles of carbonyl groups per milligram of protein with an extinction coefficient of 22,000 M1 cm1.

\section{DNA fragmentation assay}

After EBV lytic cycle induction, B958 and Raji cells were lysed in a buffer containing $10 \mathrm{mM}$ Tris ( $\mathrm{pH} 7.4$ ), 150 $\mathrm{mM} \mathrm{NaCl}, 5 \mathrm{mM}$ EDTA and $0.5 \%$ Triton X-100 for 30 min on ice. Lysates were vortexed and cleared by centrifugation at $10000 \mathrm{~g}$ for $20 \mathrm{~min}$. Fragmented DNA in the supernatant was extracted with an equal volume of neutral phenol chloroform isoamyl alcohol mixture (25:24:1) and analyzed electrophoretically on $2 \%$ agarose gels containing $0.1 \mathrm{mg} / \mathrm{ml}$ of ethidium bromide [65].

\section{Statistical analysis}

Statistical analysis was carried out by Student's t-test value, to assess the statistical significance of the obtained differences between treated and non-treated cells. A p $<0.05$ was considered to be statistically significant.

\begin{abstract}
Abbreviations
EBV: Epstein Barr virus; TPA: 12- 0-tetradecanoylphorbol-13-acetate; TBA: thiobarbituric acid reactivity; MDA: malondialdehyde; SOD: superoxide dismutase; CAT: catalase; LPDs: Iymphoproliferative diseases; PTLD: posttransplant lymphoproliferative disorder; SH: thiol; ROS: Reactive oxygen species; DNPH: 2,4-dinitrophenylhydrazine; CD: Conjugated dienes; OD: Optical density; TBA: Thiobarbituric acid; DTPA: Tris-cacodylic aciddiethylenetriaminepenta-acetic acid; $\mathrm{H}_{2} \mathrm{O}_{2}$ : Hydrogen peroxide; PBS: phosphate buffer saline.
\end{abstract}

\section{Authors' contributions}

BG and RN prepared the study design, carried out all the biological studies, analyzed and discussion of the data, and drafted the manuscript. MMJ helped with chemical analysis of the extract and correction of the manuscript. RBM carried out some biological assays and helped with the manuscript preparation. SL participated in the study design, discussion the data and helped to draft and correction of the manuscript. All authors have read and approved the final manuscript.

\section{Competing interests}

The authors declare that they have no competing interests.

Received: 5 May 2011 Accepted: 1 July 2011 Published: 1 July 2011

\section{References}

1. Crawford $\mathrm{DH}$ : Biology and disease associations of Epstein-Barr virus. Philos Trans R Soc Lond B Biol Sci 2001, 356:461-473.

2. Ring CJ: The B cell-immortalizing functions of Epstein-Barr virus. J Gen Virol 1994, 75:81.

3. Kieff E: Epstein-Barr virus and its replication. In Fields virology.. 3 edition. Edited by: Field BN, Knipe NM, Howley PM, et al. Lippincott-Raven Publishers, Philadelphia; 1999:.

4. Zur Hausen $\mathrm{H}, \mathrm{O}^{\prime}$ Neil F, Freese U: Persisting oncogenic herpes viruses induced by the tumor promoter TPA. Nature 1978, 272:373-375.

5. Hampar B, Derge JG, Martos LM: Identification of a critical period during the $S$ phase for activation of the Epstein-Barr virus by 5iododeoxyuridine. Nat New Biol 1973, 244:214-217.

6. Luka J, Kallin B, Klein G: Induction of the Epstein-Barr virus (EBV) cycle in latently infected cells by n-butyrate. Virology 1979, 94:228-231.

7. Faggioni A, Zompetta C, Grimaldi S: Calcium modulation activates Epstein-Barr virus genome in latently infected cells. Science 1986, 232:1554-1556.

8. Miller G, Lipman M: Release of infectious Epstein-Barr virus by transformed marmoset leukocytes. Proc Natl Acad Sci USA 1973, 70:190-194.

9. Spieker T, Herbst H: Distribution and phenotype of Epstein-Barr virusinfected cells in inflammatory bowel disease. Am J Pathol 2000, 1:51-57.

10. Brady G, Mac Arthur GJ, Fanel PJ: Epstein-Barr virus and Burkitt lymphoma. J Clin Pathol 2007, 60:1397-1402.

11. Raab-traub N: Epstein-Barr virus and nasopharyngeal carcinoma. Semin Cancer Biol 1992, 3:297-307.

12. Takada K: Epstein-Barr virus and gastric carcinoma. EBV Rep 1999, 6:95-100.

13. Humme S, Reisbach G, Feederle R: The EBV nuclear antigen 1 (EBNA1) enhances B cell immortalization several thousandfold. Proc Natl Acad Sci USA 2003, 100:10989-10994.

14. Kitagawa N, Goto M, Kurozumi K: Epstein-Barr virus-encoded poly (A) RNA supports Burkitt's lymphoma growth through interleukin-10 induction. EMBO J 2000, 19:6742-6750.

15. Tomkinson B, Robertson E, Kieff E: Epstein-Barr virus nuclear proteins EBNA-3A and EBNA-3C are essential for B-lymphocyte growth transformation. J Virol 1993, 67:2014-2025.

16. Montone KT, Hodinka RL, Salhany KE: Identification of Epstein-Barr virus lytic activity in post-transplantation lymphoproliferative disease. Mod Pathol 1996, 9:621-630.

17. Tao Q, Robertson KD, Manns A: Epstein-Barr virus (EBV) in endemic Burkitt's lymphoma: molecular analysis of primary tumor tissue. Blood 1998, 91:1373-1381.

18. Hong GK, Gulley ML, Feng WH: Epstein-Barr virus infection contributes to lymphoproliferative disease in SCID mose model. J Virol 2005, 79:13993-14003. 
19. Toussirot E, Roudier J: Pathophysiological links between rheumatoid arthritis and the Epstein-Barr virus: An update. Joint Bone Spine 2007, 74:418-426.

20. Sarban S, Kocyigit A, Yazar M: Plasma total antioxidant capacity, lipid peroxidation, and erythrocyte antioxidant enzyme activities in patients with rheumatoid arthritis and osteoarthritis. Clin Biochem 2005, 38:981-986.

21. Niedobitek G, Agathanggelou A, Herbst H: Epstein- Barr virus (EBV) infection in infectious mononucleosis: virus latency, replication and phenotype of EBV-infected cells. J Pathol 1997, 182:151-159.

22. Jones TG, Wood JD: Oxidant production by human B lymphocytes: detection of activity and identification of components involved. Methods 1996, 9:619-627.

23. Cerimele F, Battle T, Lynch R: Reactive oxygen signaling and MAPK activation distinguish Epstein-Barr virus (EBV)-positive versus EBVnegative Burkitt's lymphoma. Proc Natl Acad Sci USA 2005, 102:175-179.

24. Lassoued S, Ben Ameur R, Ayadi : Epstein-Barr virus induces an oxidative stress during the early stages of infection in B lymphocytes, epithelial, and lymphoblastoid cell lines. Mol Cell Biochem 2008, 313:179-186.

25. Gargouri B, Van Pellt Jos, El Feki Abd El Fatteh, Saloua Lassoued: Induction of Epstein-Barr virus (EBV) lytic cycle in vitro causes oxidative stress in lymphoblastoid B cell lines. Mol Cell Biochem 2008, 324:55-63.

26. Valko M, Leibfritz $D$, Moncol J: Free radicals and antioxidants in normal physiological functions and human disease. Int J Biochem Cell Biol 2007, 39:44-84.

27. L Hawkins Clare, Philip E: Quantification of protein modification by oxidants. Free Radical Biology Medicine 2009, 46:965-988.

28. Collins AR, Dusinska M, Gedik CM: Oxidative damage to DNA: do we have a reliable biomarker? Environ Health Perspect 1996, 04:465-469.

29. Gedik CM, Wood SG, Collins AR: Measuring oxidative damage to DNA; HPLC and the comet assay compared. Free Radic Res 1998, 29:609-615.

30. Reznick $A Z$, Packer L: Oxidative damage to proteins: spectrophotometric method for carbonyl assay. Methods Enzymol 1994, 233:357-363.

31. Nakazawa H, Genka C, Fujishima M: Pathological aspects of active oxygens/free radicals. Jpn J Physiol 1996, 46:15-32.

32. Dalle-Donne I, Giustarini D, Colombo R: Protein carbonylation in human diseases. Trends Mol Med 2003, 9:169-76.

33. Yung-Chi C: Studies on the activity of DNase associated with the replication of the Epstein-Barr virus. Virology 1980, 100:334-338.

34. Zhang M, Liu L, Cheng L: Express of plasma ROS, SOD and GSH-PX in patients with nasopharyngeal carcinoma. Lin Chuang Er Bi Yan Hou Ke Za Zhi 2003, 11:650-651.

35. Ridnour LA, Isenberg JS, Espey MG: Nitric oxide regulates angiogenesis through a functional switch involving thrombospondin-1. Proc Natl Acad Sci USA 2005, 102:13152-13747.

36. Ben Mansour R, Lassoued S, Elgaied A, haddouk S, Marzouk S, Bahloul Z, Hatam M, Aifa MS, Fakhfekh F: Enhanced reactivity to malondialdehydemodified proteins by systemic lupus erythematosus autoantibodies. Scand J Rheumatol 2010, 39:247-253.

37. Miller G, Lipman M: Release of infectious Epstein-Barr virus by transformed marmoset leukocytes. Proc Natl Acad Sci USA 1973, 70:190-194.

38. Biggin M, Bodescot M, Perricaudet M: Epstein-Barr virus gene expression in P3HR1-superinfected Raji cells. J Virol 1987, 61:3120-3132.

39. De Turenne-Tessier M, Ooka T, De The G: Characterization of an EpsteinBarr virus-induced thymidine kinase. J Virol 1986, 57:1105-1112.

40. Ooka T, Calender A, de Turenne M: Effect of arabinofuranosylthymine on the replication of Epstein-Barr virus andrelationship with a new induced thymidine kinase activity. J Virol 1983, 46:187-195.

41. Ooka T, Lenoir G, Decaussin G: Epstein-Barr virusspecific DNA polymerase in virus-nonproducer Raji cells. J Virol 1986, 58:671-675.

42. Segawa $Y$, Oda $Y$, Yamamoto $H$ : Overexpression of inducible nitric oxide synthase and accumulation of $8-\mathrm{OHdG}$ in nasopharyngeal carcinoma. Histopathology 2008, 52:213-223.

43. Gargouri B, Lassoued S, Ayadi W, ben Mansour R, Attia H, El fekih A: Lipid Peroxidation and Antioxidant System in the Tumor and in the Blood of Patients with Nasopharyngeal Carcinoma. Biol Trace Elem Res 2009.

44. Michiko K: Epstein-Barr Virus Induces Fragmentation of Chromosomal DNA during Lytic Infection. J of virology 1993, 3:7654-7658.

45. Carson DA, Seto S, Wasson DB: DNA strand breaks, NAD metabolism, and programmed cell death. Exp Cell Res 1986, 164:273-281.
46. Li $D$, Zeng $M$, Wen J: Participation of $p 53$ protein in the cellular response to DNA damage. Cancer res 1991, 23:6304-6311.

47. Tishler RB, Calderwood SK, Coleman CN: Increases in sequence specific DNA binding by $\mathrm{p} 53$ following treatment with chemotherapeutic and DNA damaging agents. Cancer Res 1993, 53:2212-2216.

48. Woo RA, MC Lure KG, Lees Miller SP: DNA dependant protein kinase acts upstream of P53 in reponse to DNA damage. Nature 1998, 394:700-704.

49. Osborn MT: Chambers TC Role of the stress-activated/c-Jun NH2-terminal protein kinase pathway in the cellular response to adriamycin and other chemotherapeutic drugs. J Biol Chem 1996, 48:30950-30955.

50. Basu S, Rozenswei KR, Youmell : The DNA dependant protein kinase participates in the activation of NF kB following DNA damage. Biochem Biophys Res Commun 1998, 247:79-83.

51. Cheng AL, Chuang SE, Lai GM: Universal activation of NF kB by anticancer drugs in cancer cell lines. Proc Am Assoc Cancer Res 1998 39:1465.

52. Chapple ILC: Reactive oxygen species and antioxidants in inflammatory diseases. J Clin Periodontol 1997, 24:287-296.

53. Gosselin J, Menezes J, D'addario M, Hiscott J, Flamand L, Lampoureux G, Oth D: Inhibition of tumor necrosis factor-alpha transcription by EpsteinBarr virus. Eur J Immunol 1991, 21:203-208.

54. Morrison TE, Mauser A, Wong A, Ting JP, Kenney SC: Inhibition of IFNgamma signialing by EBV immediatle early protein. Immunity 2001, 15:787-799.

55. Hahn AM, Huye LE, Ning S, Wzbster-Cyriaque J, Pagano JS: Interferon regulatory factor 7 is negatively regulated by EBV immediate-early gene, BZLF-1. J Virol 2005, 79:10040-10052.

56. LaJeunesse DR, Brooks K, Adamson : Epstein-Barr virus immediate-early proteins BZLF1 and BRLF1 alter mitochondrial morphology during lytic replication. Biochem Biophys Res Commun 2005, 333:438-442.

57. Martin S, Gosselin J: EBV immunossuppression of innate immunity mediated by phagocytes. Virus Research 2006, 119:134-145.

58. Larochelle B, Flamand L, Gourde P, Beauchamp D, Gosselin J: EBV infects and induces apoptosis in human neutrophils. Blood 1998, 92:291-299.

59. Hitoshi O, Daisuke Y, Shigenobu M: Inhibition of 12-Otetradecanoylphorbol-13-acetateinduced induction in epstein-barr virus early antigen in Raji cells. Cancer Letters 1983, 19:47-53.

60. Feng WH, Israel B, Raab-Traub N: Chemotherapy induces lytic EBV replication and confers ganciclovir susceptibility to EBV-positive epithelial cell tumors. Cancer Res 2002, 62:1920-1926.

61. Westphal EM, Blackstock W, Feng W: Activation of lytic Epstein-Barr virus (EBV) infection by radiation and sodium butyrate in vitro and in vivo: a potential method for treating EBV-positive malignancies. Cancer Res 2000, 60:5781-5788.

62. Oh HM, Oh JM, Choi SC: An efficient method for the rapid establishment of Epstein-Barr virus immortalization of human B lymphocytes. Cell Prolif 2003, 36:191-197.

63. Kurien BT, Scofield $\mathrm{RH}$ : Free radical mediated peroxidative damage in systemic lupus erythematosus. Life Sciences 2003, 73:1655-1666.

64. Palacio JR, Iborra A, Ulcova-Gallova Z: The presence of antibodies to oxidative modified proteins in serum from polycystic ovary syndrome patients. Clin Exp Immunol 2006, 144:217-222.

65. Ju-Hyung W, Young-Ho K, Yun-Jung C: Molecular mechanisms of curcumin-induced cytotoxicity: induction of apoptosis through generation of reactive oxygen species, down-regulation of $\mathrm{BCl}-\mathrm{XL}$ and IAP, the release of cytochrome $\mathrm{c}$ and inhibition of Akt. Carcinogenesis 2003, 7:1199-1208.

doi:10.1186/1476-511X-10-111

Cite this article as: Gargouri et al:: Induction of epstein-barr virus (EBV) lytic cycle in vitro causes lipid peroxidation, protein oxidation and DNA damage in lymphoblastoid B cell lines. Lipids in Health and Disease 2011 10:111. 